\title{
Integrative modelling and managing new landscapes and environments in de-glaciating mountain ranges: An emerging trans-disciplinary research field
}

Keywords: climate change, glacier vanishing, permafrost degradation, forest expansion, new lakes, slope stability, landscape transformation, geomorphic surface processes, adaptation strategies, risk reduction

\section{Introduction}

\section{Emerging landscapes - emerging research fields}

Changes in the global climate system may lead to corresponding changes in natural landscapes. Examples are large-scale shifts of boreal forests into tundra zones, desertification in semi-arid regions, and de-glaciations in cold mountainous areas. Strategies for adaptation to climate change impacts in such cases have to deal with future landscapes and environments, which will differ not only from the past but also from present situations. Corresponding planning of management options must be scenario-based. This involves modelling of new landscapes and environments - an important emerging research field.

The most dramatic landscape changes are currently occurring in high-latitude and high-altitude cold regions in which glaciers are rapidly disappearing. In densely populated mountainous areas, increases in natural hazards and changes in water resources, energy supply, and tourism may result. ${ }^{1}$ The following illustrates first experiences and perspectives concerning icy high-mountains. The example of the Aletsch glacier, the largest glacier in the European Alps as the focus of the corresponding UNESCO Natural World Heritage Centre Jungfrau-Aletsch, is used as an example.

So far, primarily physical aspects (topography, ice, lakes and slope stability) of de-glaciating landscapes have been modelled and considered in a future-oriented way. Over time, however, biological aspects and especially forest expansion into areas becoming icefree will play an increasingly important role. Corresponding needs will therefore grow for contributions from forestry research and engineering to this emerging trans-disciplinary field of climate change adaptation.

\section{Deglaciating mountains - options and risks}

With few exceptions (Karakoram, Pamir), glaciers are retreating worldwide at rates that exceed those of historical de-glaciations. ${ }^{2,3}$ Due to the delayed dynamic response, the extent of most glaciers still reflects climatic conditions of about the late $20^{\text {th }}$ century. The glaciers of the European Alps, for instance, would have to lose about an additional $50 \%$ of their surface area alone to adjust to present-day (2017) climatic conditions. ${ }^{4}$ Both simple and sophisticated models have provided evidence that many mountain ranges will essentially lose their glaciers within decades even under moderate scenarios of global warming. ${ }^{5,6}$ Glacial landscapes are thereby transforming for centuries if not millennia to come into per glacial landscapes composed of rocks and debris, numerous new lakes, expanding
Volume I Issue I - 2017

Wilfried Haeberli

Geography Department, University of Zurich, Switzerland

Correspondence: Wilfried Haeberli, Geography Department, University of Zurich, Switzerland Tel +4|-79-202-33-83, Email wilfried.haeberli@geo.uzh.ch

Received: August 24, 2017| Published: September 18, 2017

forests and strongly intensified geomorphic surface processes, each evolving under different time scales. Glaciers disappear within decades, permafrost in cold mountain peaks degrades over decades to centuries, vegetation and especially forests take decades to centuries as well to cover freshly exposed terrain, and formation of mature soils can last centuries to millennia. ${ }^{7-10}$ Adjustment of surface processes such as erosion/sedimentation or rock deformation/stabilization also take centuries to (many) millennia. ${ }^{11,12}$ This results in growing and long lasting disequilibria, especially concerning the stability of oversteepened and now de-buttressed lateral valley slopes and slowly destabilizing icy peaks with degrading permafrost. ${ }^{10}$

Three-dimensional model approaches combined with highresolution digital terrain information can be used to calculate realistic glacier-bed topographies for still existing but unmeasured glaciers. ${ }^{13}$ Such glacier-bed topographies represent future surface topographies of periglacial landscapes emerging from continued glacier retreat and vanishing. From this information, potential sites of future lake formation in over depend parts of original glacier beds can be determined. ${ }^{1,14}$ Such new lakes can be interesting for hydropower production, freshwater supply or tourism. However, they also increase hazards and risks for the down-valley population and infrastructure, especially in connection with the increasing probability of large rock/ice avalanches from destabilizing icy peaks into lakes newly formed in their immediate neighbourhood. ${ }^{10,15}$ Careful and integrative consideration of changing options and risks is therefore needed and must be based on model calculations with respect to the evolution of future landscapes/environments and trans-disciplinary evaluation of the technical and societal aspects involved. ${ }^{16}$

\section{The example of the UNESCO natural world heritage centre jungfrau-aletsch}

Aletsch glacier (Figure 1) is a valley glacier stretching from spectacular icy and perennially frozen peaks such as the Aletschhorn (4193ma.s.1.) and the Jungfrau (4158ma.s.1.) to the protected forested areas of the Aletschwald. With a length of still over $20 \mathrm{~km}$, it is the largest glacier in the European Alps and the focus of the UNESCO Natural World Heritage Centre Jungfrau-Aletsch. Even this large ice body with thicknesses up to several hundred meters is likely to disintegrate and to largely disappear within the 21 st century. ${ }^{17}$ This 
glacier landscape is transforming into a new landscape in longterm evolution, requiring a new interpretation and identity for the UNESCO Natural World Heritage Centre. Modelling and visualizing the development of soils and vegetation - especially forest re-growth and expansion - as interconnected with geomorphic processes and lake environments ${ }^{18-23}$ has an important potential of supporting such efforts.

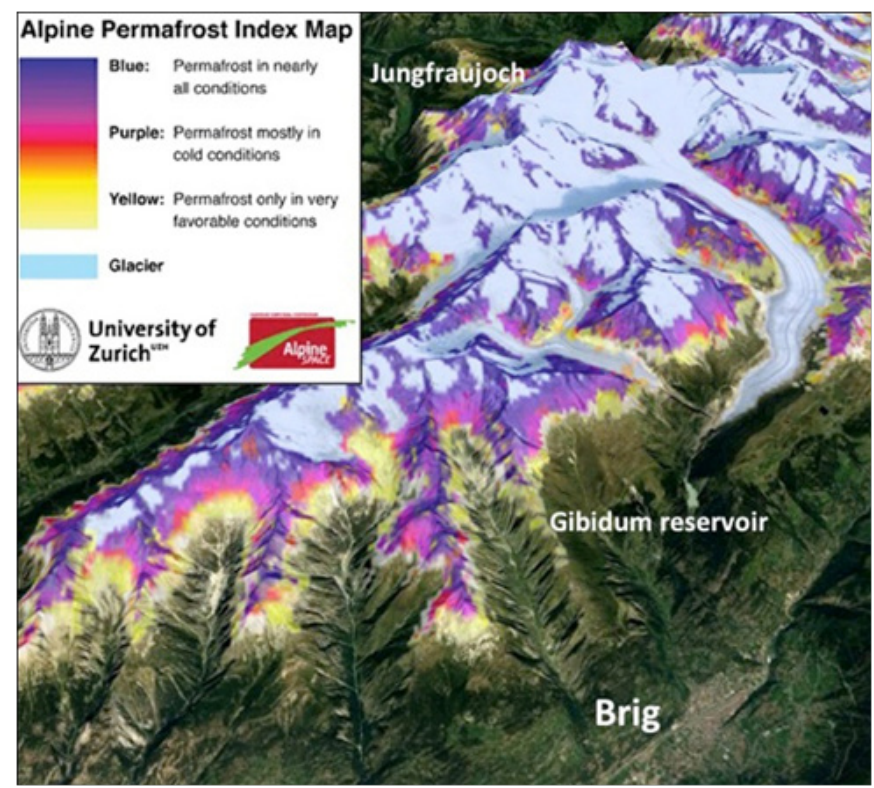

Figure I Aletsch glacier region, Swiss Alps, with modelled permafrost occurrence indicated in colour. Source, ${ }^{29}$ map implementation in Google Earth.

The bed of the glacier contains a number of pronounced overdeepenings, which may turn into lakes once the ice sets them free (Figure 2). ${ }^{14}$ Especially lakes likely to form during the second half of the 21 st century would be quite large, surrounded by over steepened, de-buttressed lateral slopes and at the very foot of steepwalled icy peaks with degrading permafrost and correspondingly decreasing slope stability. ${ }^{10,24}$ The de-buttressed, forest-covered lateral slopes of the retreating lower glacier tongue have already developed striking instabilities and large-scale mass movements during the past several decades. ${ }^{25}$ The probability of future large rock/ice avalanches or accelerated slope movements into lakes cannot be quantitatively assessed but is certainly increasing with every new lake forming at the foot of over steepened slopes and icy peaks. With this increase, the probability of large impact waves causing devastating floods down to the main valley is also increasing. The correspondingly enhanced hazard zone together with the exposure and vulnerability of the town of Brig/Naters ( $>20,000$ inhabitants) in the main valley with its important infrastructure therefore markedly raises the regional risk level.

Long-term planning and search for integrative solutions are needed. Concepts for combining risk reduction strategies with interests concerning landscape protection, hydropower production and fresh water supply could develop along the following lines. An artificial lake reservoir with a volume of about 9million $\mathrm{m}^{3}$ exists in the narrow gorge between the lower ice margin and the town of Brig (Figure 2). Enlargement of the reservoir volume could help making optimal use for hydropower production of the excess water supplied by the melting glacier during the coming decades. After a "peak flow" to be expected during these coming few decades, reduction in size of the glacier would then cause additional runoff to decrease in the second part of the century. This is also the time when dangerous lakes could start forming within the area of destabilizing icy mountains in the upper catchment. The enhanced reservoir volume could then be used as a retention capacity for flood protection and disaster prevention. Corresponding model calculations of hazardous process chains ${ }^{26,27}$ and careful engineering design of the artificial structures would be required. If combined with modern technologies for monitoring slope movements in the catchment, ${ }^{28}$ the enhanced reservoir could continue producing hydropower or supply fresh water in case of drought conditions in the valley. The latter could be of increasing importance with the expected reduction of precipitation as combined with reduced meltwater production by vanishing snow and ice during summer. Numerical modelling of intensified erosion and sedimentation processes as related to stabilizing forest expansion would help understanding, and dealing with, long-term landscape evolution and the lifetime of natural as well as artificial lakes. The enhanced reservoir at its present site in the deep and narrow gorge would be hardly visible from anywhere and could help protecting the emerging landscape of expanding forests in the upper part of the UNESCO Natural World Heritage Centre, where artificial dams and infrastructures for flood protection would be widely visible heavy disturbances. $^{29}$

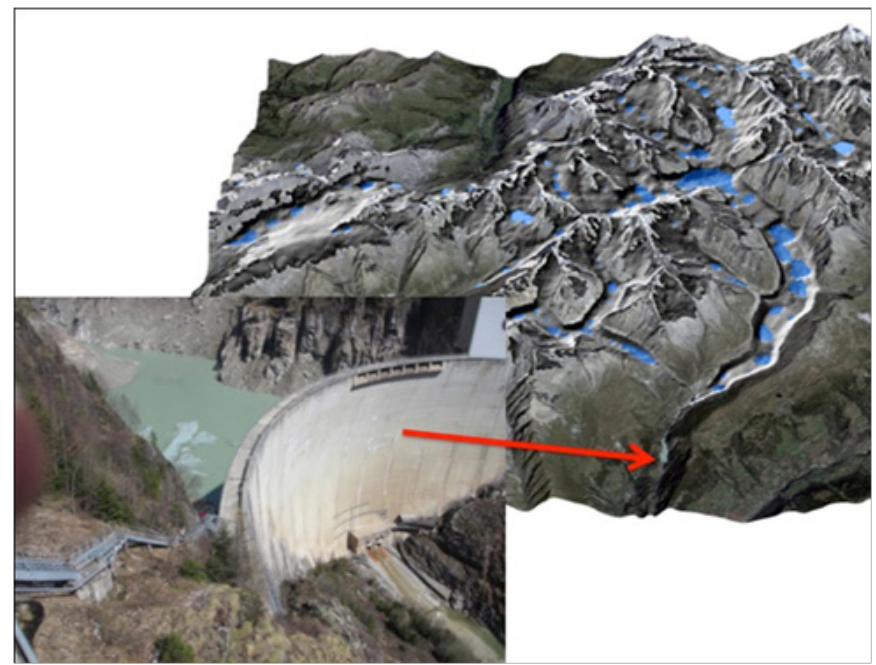

Figure 2 Dam with largely empty reservoir Gibidum (April 2017; Foto W Haeberli) and Aletsch region without the glaciers but with modelled bed overdeepenings (blue) where future lakes could possibly form (model calculation and graph, A. Linsabauer)

\section{Conclusions and perspectives}

Modelling and managing new landscapes is an important part of adaptation to impacts from climate change. It requires an integrative science of disequilibria and transitions in complex interconnected natural and socio-economic systems to be developed and applied. The increasing rate of change in nature as compared to the time involved with the required steps of planning, decision taking and realizing important practical - including major engineering - solutions makes this an urgent task: A task of integrative trans-disciplinary and participative planning with respect to applying future-oriented systems knowledge, harmonizing possibly diverging targets and looking for optimal in-time transformation in practice of corresponding findings. Contributions from the field of forestry science and engineering will thereby undoubtedly play an increasingly important role. 


\section{Acknowledgements}

Thanks are due to the journal editors for inviting and accepting this "guest contribution" about an emerging research field with important future potential for forestry research and engineering. The constructive comments and suggestions provided by an anonymous reviewer are gratefully acknowledged.

\section{Conflict of interest}

Author declares that there is no conflict of interest.

\section{References}

1. Linsbauer A, Frey H, Haeberli W, et al. Modelling glacier-bed over deepenings and possible future lakes for the glaciers in the HimalayaKarakoram region. Annals of Glaciology. 2016;57(71):119-130.

2. Global Glacier Changes: Facts and Figures. Switzerland: UNEP, World Glacier Monitoring Service. 2008. 4-45p.

3. Zemp M, Frey H, Gärtner-Roer I, et al. Historically unprecedented global glacier decline in the early 21 st century. Journal of Glaciology 2015;61(228):745-762.

4. Mernild SH, Lipscomb WH, Bahr DB, et al. Global glacier changes: A revised assessment of committed mass losses and sampling uncertainties. The Cryosphere. 2013;7:1565-1577.

5. Zemp M, Haeberli W, Hoelzle M, et al. Alpine glaciers to disappear within decades? Geophysical Research Letters. 2006;33(13):1-4.

6. Huss M and Hock R. A new model for global glacier change and sealevel rise. Frontiers in Earth Science. 2015;3:1-22.

7. Burga CA. Vegetation development on the glacier forefield Morteratsch (Switzerland). Applied Vegetation Science. 1999;2(1):17-24.

8. Cannone N, Diolaiuti G, Guglielmin M, et al. Accelerating climate change impacts on alpine glacier forefield ecosystems in the European ALPS. Ecological Applications. 2008;18(3):637-648

9. Egli M, Wernli M, Kneisel C, et al. Melting glaciers and soil development in the proglacial area Morteratsch (Swiss Alps): I Soil type chronosequence. Arctic, Antarctic, and Alpine Reserarch. 2006;38(4):499-509.

10. Haeberli W, Schaub Y, Huggel C. Increasing risks related to landslides from degrading permafrost into new lakes in de-glaciating mountain ranges. Geomorphology. 2016.

11. Ballantyne CK. Paraglacial geomorphology. Quaternary Science Revies. 2002;21(18-19):1935-2017.

12. Ballantyne CK. Paraglacial landform succession and sediment storage in deglaciated mountain valleys: theory and approaches to calibration. In: Schrott L, Hördt A, Dikau R, editors. Geophysical Applications in Geomorphology. Zeitschrift für Geomorphologie N.F. Supplement. 2003;132:1-18.

13. Haeberli W. Brief communication: On area-and slope-related thickness estimates and volume calculations for unmeasured glaciers. The Cryosphere Discussion. 2016.
14. Linsbauer A, Paul F, Haeberli W. Modeling glacier thickness distribution and bed topography over entire mountain ranges with Glabtop:Application of a fast and robust approach. Journal of Geophysical Research. 2012:117.

15. Allen SK, Linsbauer A, Randhawa SS, et al. Glacial lake outburst flood risk in Himachal Pradesh, India: An integrative and anticipatory approach considering current and future threats. Natural Hazards. 2016;84:1741-1763.

16. Haeberli W, Buetler M, Huggel C, et al. New lakes in deglaciating high-mountain regions - opportunities and risks. Climatic Change. 2016;139(2):201-214.

17. Jouvet G, Huss M, Funk M, et al. Modelling the retreat of Grosser Aletschgletscher, Switzerland, in a changing climate. Journal of Glaciology. 2011;57(206):1033-1045.

18. Bugmann H. A review of forest gap models. Climatic Change. 2001;51(3-4):259-305.

19. Carriwick JL, Heckmann T. Short-term geomorphological evolution of proglacial systems. Geomorphology. 2017:287.

20. Egli M, Wernli M, Kneisel C, et al. Melting glaciers and soil development in the proglacial area Morteratsch (Swiss Alps): II. Modeling the present and future soil state. Arctic, Antarctic, and Alpine Research. 2006;38(4):510-521.

21. Eichel J, Corenblit D, Dikau R. Conditions for feedbacks between geomorphic and vegetation dynamics on lateral moraine slopes: a biogeomorphic feedback window. Earth Surface Processes and Landforms. 2015;41(3):406-419.

22. Fontes L, Bontemps JD, Bugmann $\mathrm{H}$, et al. Models for supporting forest management in a changing environment. Forest Systems. 2010;19:8-29.

23. Lischke H, Bolliger J, Seppelt R. Dynamic spatio-temporal landscape models. In: Kienast F, Wild O, Ghosh, editors. A Changing World Challenges for Landscape Research. Springer; 2007:273-296.

24. Krautblatter M, Funk D, Günzel FK. Why permafrost rocks become unstable: A rock-ice-mechanical model in time and space. Earth Surface Processes and Landforms. 2013;38(8):876-887.

25. Kos A, Amann F, Strozzi T, et al. Contemporary glacier retreat triggers a rapid landslide response, Great Aletsch Glacier, Switzerland. Geophysical Research Letters. 2016;43(24):12466-12474.

26. Somos-Valenzuela MA, Chisolm RE, Rivas DS, et al. Modeling a glacial lake outburst flood process chain: The case of Lake Palcacocha and Huaraz, Peru. Hydrology and Earth System Sciences. 2016;20:2519-2543.

27. Worni R, Huggel C, Clague JJ, et al. Coupling glacial lake impact, dam breach, and flood processes: A modeling perspective. Geomorphology. 2014;224:161-176.

28. Strozzi T, Delaloye R, Kääb A, et al. Combined observations of rock mass movements using satellite SAR interferometry, differential GPS, airborne digital photogrammetry, and airborne photography interpretation. Journal of Geophysical Research. 2010:115(F1).

29. Boeckli L, Brenning A, Gruber S, et al. Permafrost distribution in the European Alps: Calculation and evaluation of an index map and summary statistics. The Cryosphere. 2012;6:807-820. 